\title{
Safety, Tolerability, Pharmacokinetics and Pharmacodynamics of E3024, a Novel and Selective Dipeptidyl Peptidase-IV Inhibitor, in Healthy Japanese Male Subjects: Rash Development in Men and Its Possible Mechanism"
}

\author{
Yutaka Takeuchi $^{1}$, Masayuki Namiki ${ }^{2}$, Yasumi Kitahara ${ }^{1}$, Setsuo Hasegawa ${ }^{3,4}$, Akihiro Ohnishi ${ }^{5}$, \\ Nobuyuki Yasuda $^{6}$, Takashi Inoue ${ }^{6}$, Richard Clark ${ }^{6}$, Kazuto Yamazaki ${ }^{6 \#}$ \\ ${ }^{1}$ Clinical Development, Japan/Asia Clinical Research PCU, Eisai Co., Ltd., Tokyo, Japan; ${ }^{2}$ Clinical Pharmacology, Clinical Science, \\ SOCS CFU, Eisai Co., Ltd., Tokyo, Japan; ${ }^{3}$ Sekino Clinical Pharmacology Clinic, Tokyo, Japan; ${ }^{4}$ Present Address: Pharmaspur, Inc., \\ Tokyo, Japan; ${ }^{5}$ Department of Laboratory Medicine, Daisan Hospital, Jikei University School of Medicine, Tokyo, Japan; ${ }^{6}$ Tsukuba \\ Research Laboratories, Eisai Co., Ltd., Tsukuba, Japan. \\ Email: "k5-yamazaki@hhc.eisai.co.jp
}

Received October $16^{\text {th }}, 2013$; revised November $28^{\text {th }}, 2013$; accepted December $2^{\text {nd }}, 2013$

Copyright (C) 2013 Yutaka Takeuchi et al. This is an open access article distributed under the Creative Commons Attribution License, which permits unrestricted use, distribution, and reproduction in any medium, provided the original work is properly cited.

\begin{abstract}
E3024 (3-but-2-ynyl-5-methyl-2-piperazin-1-yl-3,5-dihydro-4H-imidazo[4,5-d]pyridazin-4-one tosylate) is a dipeptidyl peptidase-IV (DPP-IV) inhibitor that was expected to be an antidiabetic agent. Its safety, tolerability, pharmacokinetics (PK), and pharmacodynamics (PD) were investigated in a randomized, double-blind, placebo-controlled, ascending single-dose study in 48 healthy Japanese male subjects. Fasted subjects were orally administered E3024 $(5,10,20,40$, or $80 \mathrm{mg}$ ) or placebo. E3024 was rapidly absorbed, with $t_{\max }$ values ranging between 0.33 and $3 \mathrm{~h}$ after dosing. The mean $\mathrm{t}_{1 / 2}$ ranged from 5.34 to $11.68 \mathrm{~h}$. $\mathrm{AUC}_{0 \text {-inf }}$ and $\mathrm{C}_{\max }$ increased dose-proportionately. PK-PD relationship of E3024 was evaluated by using an $\mathrm{I}_{\max }$ model, indicating that plasma E3024 concentrations and inhibitory effects of plasma DPP-IV activity were well correlated. The $\mathrm{IC}_{50}$ value was calculated as $33.7 \mathrm{ng} / \mathrm{mL}$, which was consistent with in vitro data. Thus, E3024 showed a good PK profile and inhibited DPP-IV dose-dependently. Of 30 subjects administered E3024, 12 (40\%) experienced adverse events (AEs). Dose escalation to $160 \mathrm{mg}$ was abandoned owing to undesired subjective/objective findings in 4 of 6 subjects receiving $40 \mathrm{mg}$ and 5 of 6 subjects receiving $80 \mathrm{mg}$. The most prominent $\mathrm{AE}$ was rash, but there were no serious AEs or deaths. The maximum tolerated dose was considered to be $20 \mathrm{mg}$. We hypothesized that histamine was a cause of the rash induction, and examined blood histamine levels of normal Fischer rats treated with E3024. Blood histamine levels were increased significantly by E3024 at $500 \mathrm{mg} / \mathrm{kg}(p<0.001)$, but not by vildagliptin or valine-pyrrolidide (DPP-IV inhibitors) at the same dose. No blood histamine increases were observed in genetically mast cell-deficient $W s / W s$ rats treated with E3024 at $500 \mathrm{mg} / \mathrm{kg}$. In in vitro assays, E3024 induced histamine release from normal rat peritoneal mast cells in a concentration-dependent manner, but not from basophils. The structure-activity relationship study suggested that a piperazine group $N$-linked to the 2-position of the 5,6-membered fused heterocyclic rings was a key structural element for triggering histamine release.
\end{abstract}

Keywords: Dipeptidyl Peptidase-IV Inhibitor; Rash; Histamine; Structure-Activity Relationship

\section{Introduction}

Dipeptidyl peptidase-IV (DPP-IV) inhibitors have been

${ }^{*}$ This clinical study was sponsored by Eisai Co., Ltd. Dr. Hasegawa was the director of the study site. Dr. Ohnishi was a paid consultant to Eisai and other pharmaceutical companies.

\#Corresponding author. considered highly attractive for the treatment of type 2 diabetes, as the inhibition of DPP-IV results in an increase of the endogenous active glucagon-like peptide-1 (GLP-1) levels [1-5]. Of this class of drugs, sitagliptin (MK-0431) [6], vildagliptin (LAF237) [7], saxagliptin (BMS-477118) [8], alogliptin (SYR-322) [9], linagliptin 
(BI-1356) [10] and anagliptin [11] have all been launched into the market for the treatment of type 2 diabetes.

E3024 (3-but-2-ynyl-5-methyl-2-piperazin-1-yl-3,5dihydro- $4 H$-imidazo[4,5-d]pyridazin-4-one tosylate) (Figure 1) with a molecular weight of 282.91 is a novel, highly selective and competitive DPP-IV inhibitor synthesized by Eisai Co., Ltd. [12-14]. E3024 inhibited the DPP-IV activity in human, mouse, rat and canine plasma with $\mathrm{IC}_{50}$ (concentration required for $50 \%$ of the maximum inhibition) values of $0.14,0.28,0.40$ and 0.36 $\mu \mathrm{mol} / \mathrm{L}$, respectively. In an oral glucose tolerance test using Zucker $f a / f a$ rats, E3024 dose-dependently increased plasma insulin levels and reduced the area under the curve (AUC) of delta blood glucose at doses of 1 and $3 \mathrm{mg} / \mathrm{kg}$. E3024 had no effect on fasting blood glucose levels in normal rats at doses of 1 or $10 \mathrm{mg} / \mathrm{kg}$. These non-clinical data had suggested that E3024 would be a novel antidiabetic agent in the treatment of postprandial hyperglycemia with a low risk of causing hypoglycemia.

The objectives of the present studies were: 1) to evaluate the safety, tolerability, pharmacokinetics (PK) and pharmacodynamics (PD) after single oral dose of E3024 in healthy Japanese male subjects, and 2) to examine possible mechanisms of rash development observed in this clinical trial, using normal and genetically mast celldeficient rats.

\section{Materials and Methods}

\subsection{Clinical Study}

This study was conducted at Sekino Clinical Pharmacology Clinic, Tokyo, Japan, in accordance with the ethical<smiles>CC#CCn1c(N2CCNCC2)nc2cnn(C)c(=O)c21</smiles>

E3024<smiles>CC#CCn1c(N2CCNCC2)nc2nc(Cc3ccccc3C(N)=O)n(Cc3ccc(C#N)cc3)c(=O)c21</smiles>

ER-319433-15 principles of the Declaration of Helsinki, good clinical practice in Japan, and International Conference on Harmonization guidelines. The clinical study protocol and informed consent documents were approved by the institutional review board of Sekino Clinical Pharmacology Clinic. Informed consent was obtained from all subjects in writing before implementation of any study-related procedures.

\subsubsection{Study Design}

This study was performed as a randomized, double-blind, placebo-controlled, escalating single-dose study. Different groups of eight subjects each were orally administered single doses of E3024 $(5,10,20,40$, or $80 \mathrm{mg}, \mathrm{n}=$ 6) or placebo ( $\mathrm{n}=2$ for $5,10,80 \mathrm{mg} ; \mathrm{n}=6$ for $20,40 \mathrm{mg}$ ) after an overnight fast of $10 \mathrm{~h}$.

E3024 was supplied by Eisai Co., Ltd. E3024 was administered in film-coated tablets containing 1,10 , or 40 $\mathrm{mg}$ of E3024. Placebo was administered in visually matching tablets.

\subsubsection{Subjects}

Healthy Japanese male subjects between 20 and 39 years of age and with body mass index (BMI) of 18.5 to 25.0 $\mathrm{kg} / \mathrm{m}^{2}$ were eligible for participation in this study. Subjects were excluded if they had a known history of any significant drug or food allergy, a significant organ dysfunction, or any clinically significant deviation from normal in medical history, physical examination findings, vital signs, electrocardiogram, or laboratory test results. Subjects with gastrointestinal, hepatic, renal, respiratory, or cardiovascular diseases; congenital metabolic disorder;

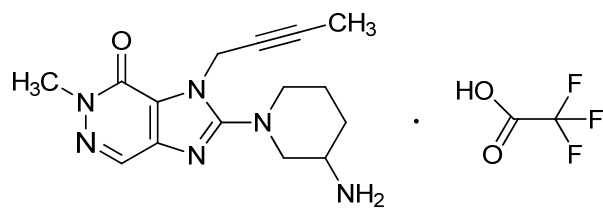

ER-319441-15<smiles>CC#CCn1c(N2CCCC(N)C2)nc2nc(Cc3ccccc3C(N)=O)n(Cc3ccc(C#N)cc3)c(=O)c21</smiles>

ER-463809-15

Figure 1. Chemical structures of E3024, ER-319441-15, ER-319433-15, and ER-463809-15. 
a positive test result for hepatitis B surface antigen, hepatitis $\mathrm{C}$ antibody or human immunodeficiency virus; or alcohol or drug abuse (or a positive urine drug test result at screening) were excluded from participation. Subjects were excluded if they had a known history of any gastrointestinal surgery that could impact upon absorption of the study drug. Subjects were also excluded if they had experienced a weight change $>10 \%$ from screening to baseline. Furthermore, any subject was excluded who had received blood within three months or donated blood (400 mL within three months or $200 \mathrm{~mL}$ within 30 days of study start), or ingested any investigational medication within four months before study start. Subjects were prohibited from any prescription drugs and over-the-counter (OTC) acid controllers within 30 days prior to and during the study, and other OTC medications within seven days prior to and during the study.

\subsubsection{Procedures}

Screening procedures, including medical history taking, physical examination, 12-lead electrocardiography (ECG), clinical laboratory evaluations, vital signs measurement, and urine drug screening, were performed from 30 days before study drug administration along with the assessment of inclusion/exclusion criteria. Eligible subjects were admitted to the study site on the day prior to dosing for base line evaluations. Subjects were required to abstain from food and beverages, except water, for at least $10 \mathrm{~h}$ prior to check-in. After the check-in evaluation was completed, subjects were provided with an appropriate meal(s); thereafter, they were required to fast (abstain from food and fluids, except water) overnight for at least $10 \mathrm{~h}$ prior to drug administration on the following day. Subjects took the study drug with $200 \mathrm{~mL}$ of water in a fasted state. Water was allowed ad libitum, except from 2 $\mathrm{h}$ before dosing to $1 \mathrm{~h}$ after dosing. Subjects were required to abstain from food up to $4.5 \mathrm{~h}$ after dosing. Subjects received a standardized meal at 4.5 (lunch) and 10.5 (dinner) $\mathrm{h}$ after dosing to assess the pharmacodynamic effects of E3024 on GLP-1, insulin, C-peptide, glucagon, and glucose. The total energy of each meal was $800 \mathrm{kcal}$, with a nutrient breakdown of $25 \%$ fat, $15 \%$ protein, and $60 \%$ carbohydrate. Subsequent meals were provided as per the regular meal schedule at the site. Subjects were to maintain an upright (seated or standing) position for at least $4.5 \mathrm{~h}$ following administration of the study drug.

\subsubsection{Pharmacokinetic Assessments}

Blood samples were collected at 0 (pre-dose), 0.33, 0.67, $1,1.5,2,3,4,6,8,12,24,36,48,72$, and $96 \mathrm{~h}$ after administration of the study drug for determination of E3024 in human plasma. Blood samples $(3 \mathrm{~mL}$ each) were col- lected from a cutaneous vein in the forearm into a sodium-heparinized tube. Samples were centrifuged $\left(4^{\circ} \mathrm{C}\right.$ at $1500 \times g$ for $15 \mathrm{~min})$ to obtain plasma. Urine samples were collected before dosing and at the following intervals: 0 to $6 \mathrm{~h}, 6$ to $12 \mathrm{~h}, 12$ to $24 \mathrm{~h}, 24$ to $48 \mathrm{~h}, 48$ to $72 \mathrm{~h}$, and 72 to $96 \mathrm{~h}$ after dosing, for determination of E3024 in human urine. Plasma and urine samples were stored at $-20^{\circ} \mathrm{C}$ until sample analysis.

Analysis was performed by Bioanalysis Section, Clinical Research Center at Eisai Co., Ltd. (Tokyo, Japan). For quantitative determination of E3024, plasma and urine samples were analyzed by a validated liquid chromatographic-tandem mass spectrometry (LC/MS/MS) method. This method was based on solid-phase extraction using Empore extraction disk plates (3M, St. Paul, $\mathrm{MN}$ ) in a 96-well format, with $0.02 \mathrm{~mL}$ (plasma) or $0.005 \mathrm{~mL}$ (urine) eluent samples injected into the $\mathrm{LC} /$ MS/MS.

Pharmacokinetic parameters were calculated from plasma and urine concentrations of E3024 by model-independent analysis using WinNonlin Professional version 4.1 (Pharsight Corp., Mountain View, CA). The dose-proportionality of maximum observed concentration $\left(\mathrm{C}_{\max }\right)$ and area under the plasma concentration-time curve from 0 to infinity ( $\mathrm{AUC}_{0 \text {-inf }}$ ) obtained from modelindependent analysis was assessed both visually and using a power model $\left(\mathrm{Y}=\alpha \mathrm{X}^{\beta} ; \mathrm{X}\right.$, dose; $\mathrm{Y}, \mathrm{C}_{\max }$ or $\left.\mathrm{AUC}_{0 \text {-inf }}\right)$. Dose proportionality was assessed based on whether $95 \%$ confidence intervals (CIs) of $\beta$ lay within the range from 0.7 to 1.3 [15].

\subsubsection{Pharmacodynamic Assessments}

For DPP-IV activity assay, blood samples were collected before dosing and at $0.33,0.67,1,1.5,2,3,4,6,8,12$, and $24 \mathrm{~h}$ after dosing. For active GLP-1 and glucagon, blood collection was performed before the meals provided at 4.5 and $10.5 \mathrm{~h}$ after dosing (lunch and dinner, respectively); and at $0.33,0.67,1,1.5,2$, and $3 \mathrm{~h}$ after the meals provided at 4.5 and $10.5 \mathrm{~h}$ after dosing. Blood (2 $\mathrm{mL}$ ) was withdrawn into tubes containing ethylenediaminetetraacetic acid (EDTA) alone (plasma DPP-IV activity assay and plasma active GLP-1) or EDTA plus aprotinin (plasma glucagon). For serum insulin, C-peptide and glucose, blood $(3 \mathrm{~mL})$ was withdrawn into serum separator tubes. For active GLP-1 samples, $50 \mu \mathrm{L}$ of DPP-IV inhibitor solution (Linco Research, Inc., St. Charles, MO) was added to each tube within $30 \mathrm{sec}$ after collection, and the tubes were gently mixed and placed on ice water immediately. After centrifugation, plasma and serum samples were stored at $-20^{\circ} \mathrm{C}$ or below until assayed.

Pharmacodynamic parameters were measured at Mitsubishi Kagaku Bio-clinical Laboratories, Inc. (now, 
Mitsubishi Chemical Medience Corp., Tokyo, Japan). DPP-IV enzyme activity was determined via incubation of 20- $\mu$ L EDTA-treated human plasma (5-fold dilution in assay) with the substrate, glycyl-L-proline 7-amido-4methyl-coumarin hydrobromide (H-Gly-Pro-AMC $\cdot \mathrm{HBr}$; $0.08 \mathrm{mmol} / \mathrm{L}$ in assay) at room temperature for $10 \mathrm{~min}$ by measurement of the release of 7-amino-4-methyl-coumarin with a multifunctional microplate reader (excitation $360 \mathrm{~nm}$; emission $465 \mathrm{~nm}$ ). Enzyme activity (1 $\mathrm{mU} / \mathrm{mL}$ ) was defined as the amount of enzyme required to degrade 1 nmole of substrate per $\min$ in $1 \mathrm{~mL}$ of reaction solution $(\mathrm{mU} / \mathrm{mL}=\mathrm{nmol} / \mathrm{mL} \cdot \mathrm{min})$. The range of reliable quantitation was 0.05 to $20.0 \mathrm{mU} / \mathrm{mL}$. Active GLP-1 (GLP-1-[7-36]amide and GLP-1-[7-37]) was assayed with an enzyme-linked immunosorbent assay (ELISA) kit (Linco Research, Inc.). The lower limit of reliable quantitation was estimated to be $5.00 \mathrm{pmol} / \mathrm{L}$. If concentrations could be calculated from measured fluorescence intensity, the values were used in the analysis even if less than $5.00 \mathrm{pmol} / \mathrm{L}$. If concentrations could not be calculated, the measured values were defined as zero. Insulin, C-peptide, glucagon, and glucose concentrations were measured by standard methods in the laboratory, i.e. immunoradiometric assay for insulin, radioimmunoassay for glucagon and C-peptide, and enzymatic assay for glucose.

For pharmacodynamic parameters, the values measured and changes from baseline at each time point were summarized using descriptive statistics by dose. Percent inhibition of plasma DPP-IV activity for each subject was plotted against plasma E3024 concentration, and an $\mathrm{I}_{\max }$ model (effect $=\mathrm{I}_{\max } \cdot \mathrm{C} /\left(\mathrm{IC}_{50}+\mathrm{C}\right)$; where $\mathrm{C}$ is plasma E3024 concentration) was used to determine the $\mathrm{IC}_{50}$ values.

\subsubsection{Safety Assessments}

The following data were collected during the study to assess safety: physical examination findings, vital signs (blood pressure, pulse rate, respiratory rate, and body temperature), body weight, 12-lead ECGs, and clinical laboratory parameters (hematology, biochemistry and urinalysis). In the case of a clinically significant abnormal value, the evaluation was to be repeated until the value was within an acceptable or normal range. AEs were to be followed to resolution.

From subjects who had rash in the 40-mg group, blood samples were collected for measurement of non-specific immunoglobulin E (IgE) at 24 and $96 \mathrm{~h}$, and drug-induced lymphocyte stimulation test (DLST) at $96 \mathrm{~h}$ after dosing. In the same way, from subjects who had rash in the 80-mg group, blood samples were collected for measurement of IgE, serotonin, histamine, and substance $\mathrm{P}$ at onset of rash (the nearest pharmacokinetic time point), 24 and $96 \mathrm{~h}$ after dosing. Blood samples, which were collected for clinical laboratory tests the day before dosing, were also used to obtain baseline data for IgE, histamine and substance $\mathrm{P}$. These additional assays were performed at the study site for $\mathrm{IgE}$, and at Mitsubishi Kagaku Bio-clinical Laboratories, Inc. for DLST, serotonin, histamine and substance $\mathrm{P}$.

The numbers of subjects with AEs were tabulated. For clinical laboratory parameters (except urinalysis), vital signs, body weight, and 12-lead ECG parameters, the values measured and changes from baseline at each time point were summarized using descriptive statistics by dose. For urinalysis, cross tables were prepared.

\subsection{Non-Clinical in Vivo and in Vitro Studies}

\subsubsection{Chemicals}

E3024, vildagliptin, valine-pyrrolidide (a DPP-IV inhibitor [16]), ER-319441-15 (trifluoroacetate salt form of ER-319441 (2-(3-amino-piperidin-1-yl)-3-but-2-ynyl-5methyl-3,5-dihydro-4H-imidazo[4,5- $d$ ]pyridazin-4-one)), ER-319433-15 (trifluoroacetate salt form of ER-319433 (2-\{[7-(but-2-yn-1-yl)-1-[(4-cyanophenyl)methyl]-6-oxo8-(piperazin-1-yl)-6,7-dihydro-1 $H$-purin-2-yl]methyl benzamide)), and ER-463809-15 (trifluoroacetate salt form of ER-463809 (2-(\{8-(3-aminopiperidin-1-yl)-7-(but-2yn-1-yl)-1-[(4-cyanophenyl)methyl]-6-oxo-6,7-dihydro$1 H$-purin-2-yl $\}$ methyl)benzamide)) were synthesized in our laboratories. Chemical structures of ER-319441-15, ER-319433-15 and ER-463809-15 are indicated in Figure 1. A23187 (a calcium ionophore) and dimethyl sulfoxide (DMSO) were purchased from Sigma-Aldrich (St. Louis, MO). Methylcellulose (MC) was obtained from Wako Pure Chemical Industries, Ltd. (Osaka, Japan).

\subsubsection{Animals}

Five-week-old normal male Fischer (F344/Jcl) rats were purchased from CLEA Japan, Inc. (Tokyo, Japan). Fiveweek-old male Slc:WsRC-Ws/Ws $(W s / W s)$ and Slc: WsRC-+/+ (+/+; wild-type homozygous) rats were obtained from Japan SLC, Inc. (Hamamatsu, Japan). The rats were provided with a commercial diet (MF; Oriental Yeast, Tokyo, Japan) and water ad libitum, and were kept under conventional conditions of controlled temperature, humidity and lighting $\left(22 \pm 2^{\circ} \mathrm{C}, 55 \pm 5 \%\right.$ and a 12-hr light/dark cycle with lights on at 07:00 a.m.). All procedures were conducted according to the Eisai Animal Care Committee's guideline.

\subsubsection{Determination of Plasma Compound Concentrations in Rats}

Compounds were suspended in $0.5 \% \mathrm{MC}$, and administered to Fischer rats aged eight weeks orally $(10 \mathrm{~mL} / \mathrm{kg})$. 
After 30 min later, blood samples were taken from the tail vein $(\sim 200 \mu \mathrm{L})$. Plasma was obtained after centrifugation. The concentrations of compounds were determined by the LC/MS/MS method.

\subsubsection{Effects of Compounds on Blood Histamine Levels}

Compounds or vehicle $(0.5 \% \mathrm{MC}, 10 \mathrm{~mL} / \mathrm{kg})$ were orally administered to seven-week-old Fischer rats. Blood (20 $\mu \mathrm{L})$ was taken from the tail vein at $0,0.5$ or $1 \mathrm{~h}$ after administration, and was mixed with saline containing 50 $\mathrm{mg} / \mathrm{mL}$ EDTA $(20 \mu \mathrm{L})$. Blood histamine levels were determined using a Histamine ELISA kit (Immunotech; Medical \& Biological Laboratories Co., Ltd., Nagoya, Japan).

\subsubsection{Effects of Compounds on Histamine Release from Rat Peritoneal Mast Cells and Basophils}

Peritoneal exudate cells (PECs) were used for studies on histamine release from rat mast cells [17]. Seven-weekold Fischer rats were sacrificed by exsanguination from the carotid artery under deep diethyl ether anesthesia. PECs were recovered by washing the peritoneal cavity with the injection of $10 \mathrm{~mL}$ of $\mathrm{Ca}^{2+}$-free Dulbecco's phosphate-buffered saline (D-PBS(-)) containing 5 units/ $\mathrm{mL}$ of heparin and $0.1 \%$ bovine serum albumin, followed by gentle massage for $90 \mathrm{sec}$. The peritoneal fluids were pooled and spun down at $1200 \mathrm{rpm}$ for $5 \mathrm{~min}$ at $4^{\circ} \mathrm{C}$. Cells were washed in D-PBS(-) three times, and resuspended in D-PBS(-).

We used whole blood cells to investigate histamine release from basophils according to the method of Kowal et al. [18]. Heparinized whole blood was obtained from the posterior vena cava of seven-week-old Fischer rats under deep diethyl ether anesthesia, and whole blood was diluted to $1 / 25$ with D-PBS(-).

Mast cells $\left(10^{4}\right.$ cells/180 $\mu \mathrm{L} /$ tube $)$ or whole blood cells
(180 $\mu \mathrm{L}$ of the diluted whole blood/tube) were incubated with a test compound or vehicle (DMSO) for $30 \mathrm{~min}$ at $37^{\circ} \mathrm{C}$. A23187 was used as a control compound to release histamine. Addition of $0.1 \%$ Triton X-100 to the tubes was performed to obtain total histamine content of cells (Hc). Blank tubes containing only cells and buffers were used for non-specific spontaneous release (Hs) during the reaction. Histamine levels were determined using an ELISA kit. The percentage of histamine release induced by a compound was calculated according to the following formula:

$$
\{(\mathrm{Ht}-\mathrm{Hs}) /(\mathrm{Hc}-\mathrm{Hs})\} \times 100
$$

where $\mathrm{Ht}=$ test release caused by a compound, $\mathrm{Hs}=$ spontaneous release, and $\mathrm{Hc}=$ total cellular histamine content [17].

\subsubsection{Statistical Analysis}

Data are expressed as the mean \pm standard error of the mean (S.E.M.). A probability ( $p$ ) value $<0.05$ (two-sided) was considered statistically significant. In the comparison of data, we performed two-way repeated measures analysis of variance followed by Bonferroni's test as a post hoc test, or one-way analysis of variance followed by Dunnett's test as a post hoc test, using GraphPad Prism Version 6 (GraphPad Software, Inc., San Diego, CA).

\section{Results}

\subsection{Subject Demographics}

A total of 48 healthy Japanese male subjects were enrolled. Subject demographics were similar across dose groups (Table 1). The mean age of enrolled subjects was $24.3 \pm 3.4$ years (mean \pm standard deviation); range, 20 35 years), with an average BMI of $21.47 \pm 1.48 \mathrm{~kg} / \mathrm{m}^{2}$ (range, $19.2-24.2 \mathrm{~kg} / \mathrm{m}^{2}$ ). All subjects completed the study.

Table 1. Demographic characteristics of the study population.

\begin{tabular}{lccccc}
\hline E3024 dose & No. of subjects & Age (years) & Height $(\mathrm{cm})$ & Body weight $(\mathrm{kg})$ & BMI $\left(\mathrm{kg} / \mathrm{m}^{2}\right)$ \\
\hline $5 \mathrm{mg}$ & 6 & $22.5 \pm 2.0$ & $169.80 \pm 4.07$ & $62.02 \pm 6.01$ & $21.48 \pm 1.30$ \\
$10 \mathrm{mg}$ & 6 & $23.7 \pm 3.8$ & $175.95 \pm 3.69$ & $68.87 \pm 4.22$ & $22.27 \pm 1.50$ \\
$20 \mathrm{mg}$ & 6 & $26.7 \pm 5.4$ & $170.05 \pm 4.90$ & $59.77 \pm 5.14$ & $20.65 \pm 1.18$ \\
$40 \mathrm{mg}$ & 6 & $23.5 \pm 1.5$ & $170.12 \pm 7.76$ & $59.48 \pm 4.72$ & $20.55 \pm 0.94$ \\
$80 \mathrm{mg}$ & 6 & $26.2 \pm 4.9$ & $169.68 \pm 6.62$ & $62.48 \pm 5.26$ & $21.70 \pm 1.45$ \\
All E3024-treated & 30 & $24.5 \pm 3.9$ & $171.12 \pm 5.77$ & $62.52 \pm 5.86$ & $21.33 \pm 1.37$ \\
All placebo-treated & 18 & $23.9 \pm 2.4$ & $171.34 \pm 6.38$ & $63.78 \pm 6.63$ & $21.69 \pm 1.67$ \\
All subjects & 48 & $24.3 \pm 3.4$ & $171.20 \pm 5.94$ & $63.00 \pm 6.12$ & $21.47 \pm 1.48$ \\
\hline
\end{tabular}

BMI, body mass index. Mean \pm standard deviation. 


\subsection{Pharmacokinetic Profiles}

Pharmacokinetic profiles of E3024 were assessed in 30 healthy adult male subjects each receiving a single oral dose of E3024 (5, 10, 20, 40, or $80 \mathrm{mg})$ under fasted conditions. Mean pharmacokinetic profiles after the single dose are presented in Figure 2(a), and E3024 single-dose pharmacokinetic parameters are provided in Table 2. E3024 was rapidly absorbed after dosing, with a median $\mathrm{t}_{\max }$ of $0.83-1.50 \mathrm{~h}$; thereafter, concentrations declined with a mean $t_{1 / 2}$ of $5.34-11.68 \mathrm{~h}$. After administration of 5 to $80 \mathrm{mg}$ E3024, mean $\mathrm{C}_{\max }$ increased from 37 to $819 \mathrm{ng} / \mathrm{mL}$, and mean $\mathrm{AUC}_{0 \text {-inf }}$ increased from 223 to $3571 \mathrm{ng} \cdot \mathrm{h} / \mathrm{mL}$. Mean $\mathrm{CL} / \mathrm{F}$ ranged between 23.0 and $25.4 \mathrm{~L} / \mathrm{h}$, remaining nearly constant over the studied dose range. Mean $\mathrm{V}_{\mathrm{z}} / \mathrm{F}$ showed slightly higher values at doses of 40 and $80 \mathrm{mg}$.

Dose-proportionality for $\mathrm{C}_{\max }$ and $\mathrm{AUC}_{0 \text {-inf }}$ obtained from model-independent analysis was assessed both visually and using a power model $\left(\mathrm{Y}=\alpha \mathrm{X}^{\beta}\right)$. Plots of individual $\mathrm{C}_{\max }$ and $\mathrm{AUC}_{0 \text {-inf }}$ values against dose are presented in Figures 2(b) and (c), respectively. Point estimates of $\beta$ in $\mathrm{C}_{\max }$ and $\mathrm{AUC}_{0 \text {-inf }}$ were 1.077 and 0.993, respectively, indicating that both values were approximately 1 . The $95 \% \mathrm{CIs}$ of $\beta$ for $\mathrm{C}_{\max }$ and $\mathrm{AUC}_{0 \text {-inf }}$ were $1.000-1.153$ and $0.925-1.061$, respectively, showing that both $\mathrm{C}_{\max }$ and $\mathrm{AUC}_{0 \text {-inf }}$ following a single oral dose of E3024 (5 - $80 \mathrm{mg}$ ) increased dose-proportionately.

Urinary pharmacokinetic parameters of E3024 are provided in Table 3. Mean cumulative excretion rate (fraction of drug excreted unchanged in urine; fe) reached a plateau within $96 \mathrm{~h}$ after dosing and ranged between $52.3 \%$ and $63.2 \%$. Mean cumulative excretion rate and renal clearance $\left(\mathrm{CL}_{\mathrm{R}}\right)$ remained nearly constant over the studied dose range.
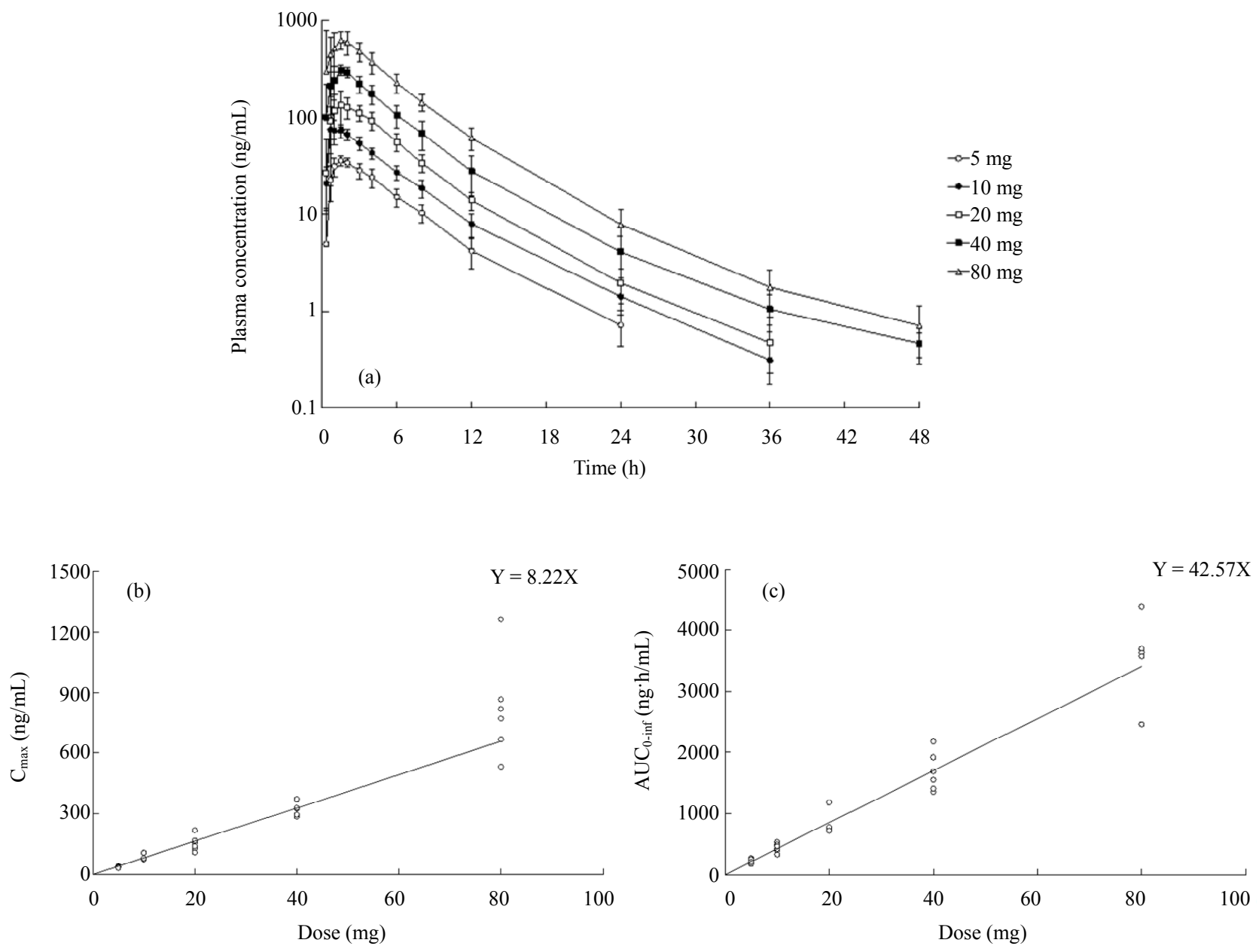

Figure 2. (a) Mean plasma E3024 concentrations (semilogarithmic plotting) after single oral doses of E3024 (5 - 80 mg) in healthy adult male subjects under fasted conditions. Each plotted point represents mean value and standard deviation (six subjects per group). Relationship between dose and $C_{\max }$ (b) or $\mathrm{AUC}_{0 \text {-inf }}$ (c) after single oral doses of E3024 (5 - $80 \mathrm{mg}$ ) in healthy adult male subjects under fasted conditions. Each point represents an individual value. Solid lines are the results of application of a linear regression model from a method of least squares. 
Safety, Tolerability, Pharmacokinetics and Pharmacodynamics of E3024, a Novel and Selective Dipeptidyl

Peptidase-IV Inhibitor, in Healthy Japanese Male Subjects: Rash Development in Men and Its Possible Mechanism

Table 2. Summary of pharmacokinetic parameters for plasma E3024 obtained by model-independent analysis.

\begin{tabular}{cccccc}
\hline \multirow{2}{*}{ Parameter } & \multicolumn{5}{c}{ E3024 dose } \\
\cline { 2 - 6 } & $5 \mathrm{mg}$ & $10 \mathrm{mg}$ & $20 \mathrm{mg}$ & $40 \mathrm{mg}$ & $80 \mathrm{mg}$ \\
\hline $\mathrm{C}_{\max }(\mathrm{ng} / \mathrm{mL})$ & $36.7 \pm 3.2$ & $87.6 \pm 15.5$ & $152.4 \pm 37.9$ & $323.9 \pm 30.7$ & $819.3 \pm 247.5$ \\
$\mathrm{t}_{\max }(\mathrm{h})$ & $1.50(1.00-2.00)$ & $0.83(0.67-2.00)$ & $1.50(0.67-3.00)$ & $1.50(1.00-2.00)$ & $1.25(0.33-2.00)$ \\
$\mathrm{AUC}_{0 \text {-inf }}(\mathrm{ng} \cdot \mathrm{h} / \mathrm{mL})$ & $223.0 \pm 38.1$ & $440.4 \pm 71.9$ & $812.6 \pm 183.8$ & $1684.9 \pm 314.9$ & $3571.1 \pm 623.2$ \\
$\mathrm{t}_{1 / 2}(\mathrm{~h})$ & $5.34 \pm 1.43$ & $5.75 \pm 1.68$ & $6.08 \pm 1.21$ & $11.68 \pm 5.20$ & $9.43 \pm 2.16$ \\
$\mathrm{CL} / \mathrm{F}(\mathrm{L} / \mathrm{h})$ & $23.0 \pm 4.0$ & $23.3 \pm 4.1$ & $25.4 \pm 4.3$ & $24.4 \pm 4.3$ & $23.1 \pm 4.9$ \\
$\mathrm{~V}_{2} / \mathrm{F}(\mathrm{L})$ & $175.1 \pm 47.7$ & $186.5 \pm 30.0$ & $217.9 \pm 31.0$ & $416.8 \pm 194.9$ & $318.6 \pm 108.6$ \\
\hline
\end{tabular}

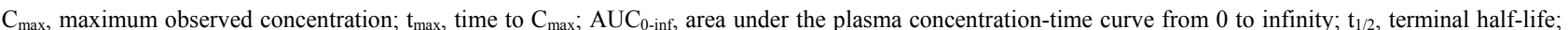
$\mathrm{CL}$, clearance; F, bioavailability; $\mathrm{CL} / \mathrm{F}$, apparent clearance; $\mathrm{V}_{\mathrm{z}}$, volume of distribution during the terminal phase; $\mathrm{V}_{\mathrm{z}} / \mathrm{F}$, apparent volume of distribution during the terminal phase. Mean \pm standard deviation, except $t_{\max } \cdot t_{\max }$, median (minimum - maximum). Six subjects per group.

Table 3. Summary of pharmacokinetic parameters for urine E3024 obtained by model-independent analysis.

\begin{tabular}{cccccc}
\hline \multirow{2}{*}{ Parameter } & \multicolumn{5}{c}{ E3024 dose } \\
\cline { 2 - 6 } & $5 \mathrm{mg}$ & $10 \mathrm{mg}$ & $20 \mathrm{mg}$ & $40 \mathrm{mg}$ & $80 \mathrm{mg}$ \\
\hline $\mathrm{Ae}(\mathrm{mg})$ & $3.16 \pm 0.56$ & $5.58 \pm 0.93$ & $11.01 \pm 2.03$ & $20.93 \pm 3.14$ & $47.23 \pm 14.05$ \\
$\mathrm{fe}(\%)$ & $63.2 \pm 11.1$ & $55.8 \pm 9.3$ & $55.0 \pm 10.1$ & $52.3 \pm 7.9$ & $59.0 \pm 17.6$ \\
$\mathrm{CL}_{\mathrm{R}}(\mathrm{mL} / \mathrm{min})$ & $236.6 \pm 14.2$ & $211.2 \pm 6.3$ & $227.2 \pm 13.6$ & $208.4 \pm 14.7$ & $215.7 \pm 42.3$ \\
\hline
\end{tabular}

Ae, amount of unchanged drug excreted in urine; fe, fraction of drug excreted unchanged in urine; $\mathrm{CL}_{\mathrm{R}}$, renal clearance. Mean \pm standard deviation. Six subjects per group.

\subsection{Pharmacodynamic Profiles}

The DPP-IV inhibitory activity of E3024 was measured up to $24 \mathrm{~h}$ after administration of the study drug to assess the pharmacodynamic profile. Figure 3(a) shows the time course of plasma DPP-IV activity inhibition after a single oral dose $(5-80 \mathrm{mg})$ of E3024 or placebo. The inhibition of DPP-IV activity in the E3024 groups increased immediately after drug administration, reached peak levels 1 to $2 \mathrm{~h}$ after administration, then decreased to the pre-dose levels at $24 \mathrm{~h}$ after administration. On the other hand, DPP-IV inhibitory activity was not observed in the placebo group. The DPP-IV inhibitory activity of E3024 increased dose-dependently. The relationships between plasma concentration of E3024 and inhibition of DPP-IV activity after single oral administration of E3024 (5 - $80 \mathrm{mg}$ ) were analyzed using the $\mathrm{I}_{\max }$ model. As shown in Figure 3(b), the relationship between plasma concentration of E3024 and inhibition of DPP-IV activity was well-adapted to the $\mathrm{I}_{\max }$ model, with an $\mathrm{IC}_{50}$ value of $33.7 \mathrm{ng} / \mathrm{mL}$.

Following administration of the study drug, measurement of active GLP-1, insulin, C-peptide, glucagon, and glucose concentrations was performed within $3 \mathrm{~h}$ after lunch and dinner, which were started at 4.5 and $10.5 \mathrm{~h}$ after dosing, respectively. The time course of active GLP-1 concentrations after single oral doses of E3024 (5 - $80 \mathrm{mg}$ ) or placebo is shown in Figure 4. The levels of active GLP-1 increased immediately after food intake and reached maximum concentrations $20 \mathrm{~min}$ after food intake, then decreased. In the E3024 groups receiving doses of $20 \mathrm{mg}$ or more, although there were large variations in measured values, the increase in active GLP-1 after food intake was larger than that in the placebo group. In addition, the increase in active GLP-1 tended to be larger after lunch compared with after dinner. An increase in insulin and C-peptide, and a decrease in glucagon and glucose were observed after food intake in all groups, but a dose-dependent change was not observed (data not shown).

\subsection{Safety and Tolerability}

No deaths or serious AEs were reported following single oral doses of 5 to $80 \mathrm{mg}$ E3024. AEs observed in this study are listed in Table 4. Twenty-three events of subjective symptoms or objective findings (erythema, rash, pruritus, diarrhea, feeling hot, conjunctival hyperemia, and headache) occurred in ten subjects and three events of abnormal changes in laboratory values (blood amylase increased, alanine aminotransferase (ALT) increased, and lipase increased) in three subjects. All of these AEs occurred in E3024 groups. No abnormal changes were observed in 12-lead ECG parameters, vital signs, or body weight. The number of AEs in each of the $5 \mathrm{mg}, 10 \mathrm{mg}$, and $20 \mathrm{mg}$ E3024 groups was one event in one (16.7\%) of six subjects, while that in the $40 \mathrm{mg}$ group was five events in four $(66.7 \%)$ of six subjects and that in the 80 mg group was 18 events in five of six subjects $(83.3 \%)$. Thus, the incidence of AEs increased when $40 \mathrm{mg}$ or more of E3024 was administered.

Rash developed in four subjects each of the $40 \mathrm{mg}$ and 

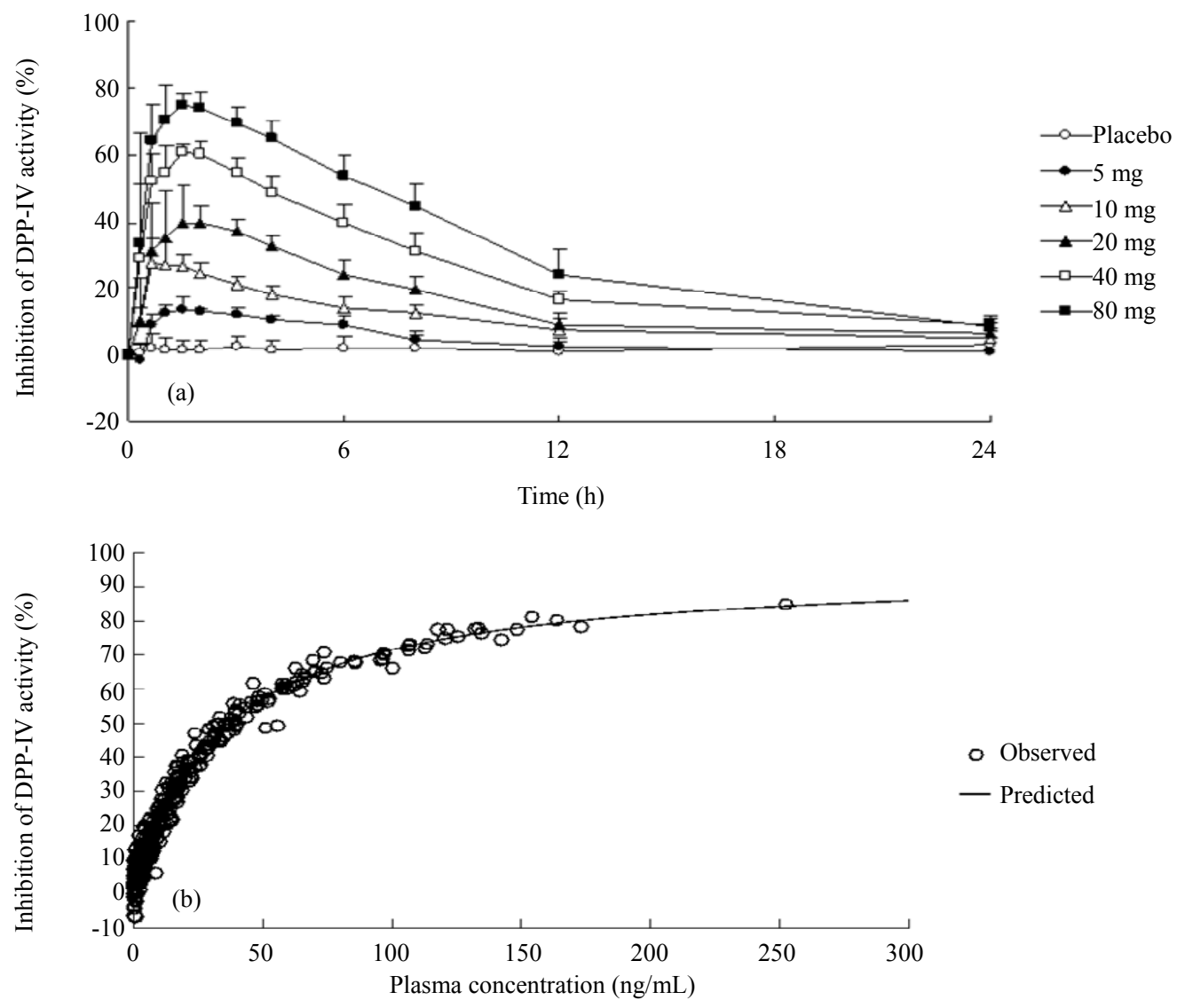

Figure 3. (a) Time course of inhibition of plasma dipeptidyl peptidase-IV (DPP-IV) activity after single oral doses of E3024 (5 - $80 \mathrm{mg}$ ) or placebo in healthy adult male subjects. Each plot represents mean values and standard deviations (six subjects for each E3024 group, 18 subjects for placebo); (b) Relationship between plasma E3024 concentration and inhibition of DPP-IV activity. Observed: Plots of 1/5 of actual plasma E3024 concentrations and inhibition of DPP-IV activity at each time point (plasma was diluted to $1 / 5$ in assay for DPP-IV activity). Predicted: $I_{\max }$ model prediction of plasma E3024 concentrations and inhibition of DPP-IV activity.

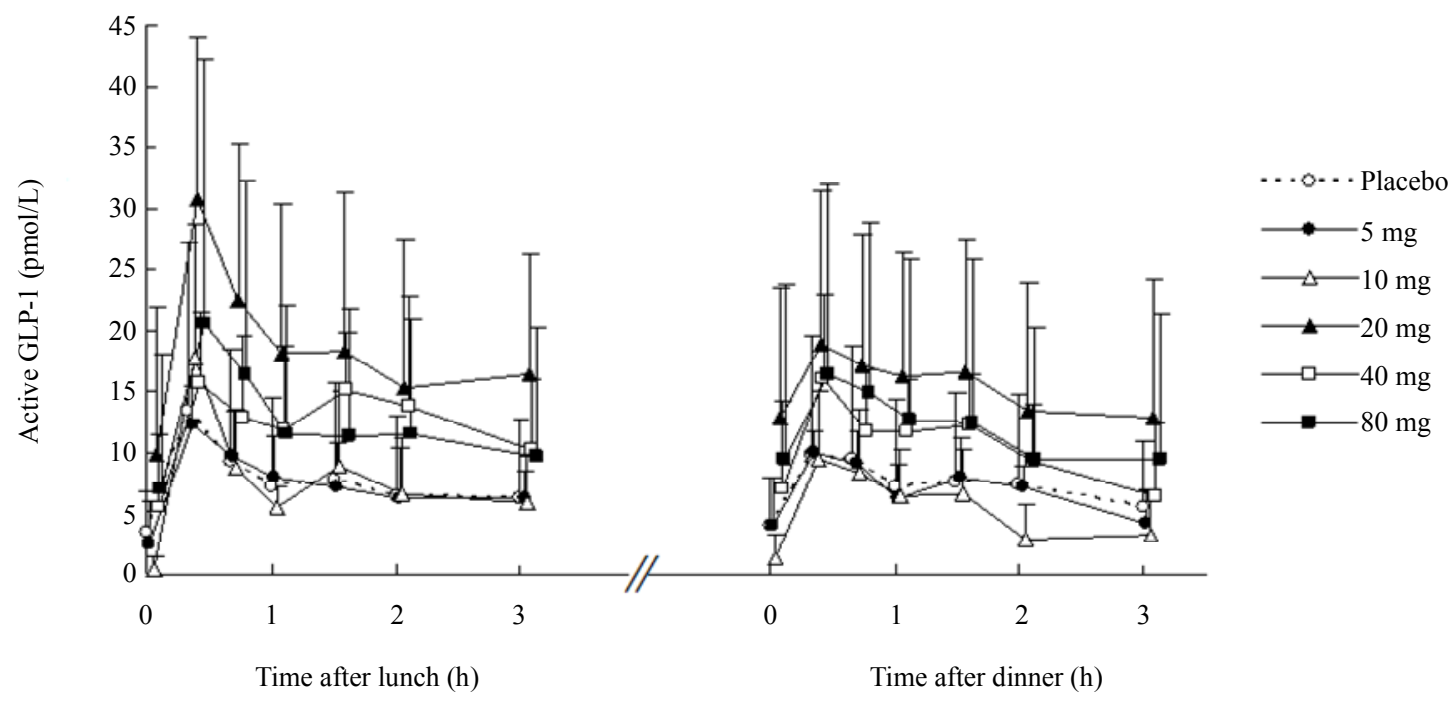

Figure 4. Time course of active glucagon-like peptide-1 (GLP-1; GLP-1-[7-36]amide and GLP-1-[7-37]) concentrations after single oral doses of E3024 (5 - $80 \mathrm{mg}$ ) or placebo in healthy adult male subjects. Each plot represents mean values and standard deviations (six subjects for each E3024 group, 18 subjects for placebo). 
$80 \mathrm{mg}$ groups. The onset of rash was $31-83$ and $4-28$ min after dosing in the $40 \mathrm{mg}$ and $80 \mathrm{mg}$ groups, respectively. Additional tests were conducted for the subjects with rash. In the four subjects receiving $40 \mathrm{mg}$, no changes were observed in eosinophil fraction or nonspecific IgE, and DLST was also negative. The results of additional tests of the four subjects receiving $80 \mathrm{mg}$ are shown in Table 5. No changes were observed in eosinophil fraction, IgE, or serotonin, but three of the four subjects (subjects A, C, and D) showed a trend to increased histamine levels immediately after the onset of rash following study drug administration. Substance $P$ showed an upward tendency in two subjects (subjects B and D).

Although all AEs occurring in this study were mild

Table 4. Summary of adverse events after single oral dose of E3024.

\begin{tabular}{|c|c|c|c|c|c|c|}
\hline & \multicolumn{6}{|c|}{ E3024 dose } \\
\hline & Placebo $(n=18)$ & $5 \mathrm{mg}(\mathrm{n}=6)$ & $10 \mathrm{mg}(\mathrm{n}=6)$ & $20 \mathrm{mg}(\mathrm{n}=6)$ & $40 \mathrm{mg}(\mathrm{n}=6)$ & $80 \mathrm{mg}(\mathrm{n}=6)$ \\
\hline $\begin{array}{l}\text { Number (\%) of subjects experiencing } \\
\text { any adverse events }\end{array}$ & $0(0.0 \%)$ & $1(16.7 \%)$ & $1(16.7 \%)$ & $1(16.7 \%)$ & $4(66.7 \%)$ & $5(83.3 \%)$ \\
\hline Headache & 0 & 0 & 0 & 0 & 0 & 1 \\
\hline Conjunctival hyeremia & 0 & 0 & 0 & 0 & 0 & 4 \\
\hline Diarrhea & 0 & 0 & 0 & 0 & 0 & 3 \\
\hline Erythema & 0 & 0 & 1 & 0 & 0 & 0 \\
\hline Pruritus & 0 & 0 & 0 & 0 & 1 & 1 \\
\hline Rash & 0 & 0 & 0 & 0 & 4 & 4 \\
\hline Feeling hot & 0 & 0 & 0 & 0 & 0 & 4 \\
\hline ALT increased & 0 & 0 & 0 & 1 & 0 & 0 \\
\hline Amylase increased & 0 & 1 & 0 & 0 & 0 & 0 \\
\hline Lipase increased & 0 & 0 & 0 & 0 & 0 & 1 \\
\hline
\end{tabular}

ALT, alamine aminotransferase.

Table 5. Individual data for additional tests in subjects having rash in the $80 \mathrm{mg}$ group.

\begin{tabular}{|c|c|c|c|c|c|c|}
\hline Subject & Time of treatment & Eosinophil (\%) & Non-specific IgE (U/mL) & Serotonine $(\mathrm{ng} / \mathrm{mL})$ & Histamine (ng/mL) & Substance $\mathrm{P}(\mathrm{pg} / \mathrm{mL})$ \\
\hline \multirow{4}{*}{ A } & Day -1 & 10.6 & 106 & - & 1.09 & \multirow{4}{*}{ Not tested } \\
\hline & Rash onset ( $0.33 \mathrm{~h}$ after dose) & 8.0 & 144 & 141 & 1.60 & \\
\hline & $24 \mathrm{~h}$ after dose & 7.2 & 157 & 166 & 0.76 & \\
\hline & $96 \mathrm{~h}$ after dose & 5.4 & 187 & 159 & 1.28 & \\
\hline \multirow{4}{*}{ B } & Day -1 & 2.3 & 112 & - & 0.41 & 105.24 \\
\hline & Rash onset ( $1 \mathrm{~h}$ after dose) & 2.1 & 154 & 198 & 0.42 & 176.09 \\
\hline & $24 \mathrm{~h}$ after dose & 2.4 & 162 & 153 & 0.29 & 120.70 \\
\hline & $96 \mathrm{~h}$ after dose & 1.4 & 195 & 189 & 0.28 & 100.74 \\
\hline \multirow{4}{*}{$\mathrm{C}$} & Day -1 & 0.8 & 112 & - & 0.24 & 115.71 \\
\hline & Rash onset (1.5 h after dose) & 0.6 & 154 & 114 & 0.43 & 116.39 \\
\hline & $24 \mathrm{~h}$ after dose & 0.5 & 162 & 131 & 0.26 & 114.58 \\
\hline & $96 \mathrm{~h}$ after dose & 0.7 & 195 & 149 & 0.19 & 105.35 \\
\hline \multirow{4}{*}{$\mathrm{D}$} & Day -1 & 2.0 & 59 & - & 0.42 & 83.74 \\
\hline & Rash onset ( $0.67 \mathrm{~h}$ after dose) & 1.3 & 57 & 165 & 0.57 & 127.67 \\
\hline & $24 \mathrm{~h}$ after dose & 1.4 & 65 & 159 & 0.92 & 80.83 \\
\hline & $96 \mathrm{~h}$ after dose & 2.3 & 84 & 190 & 0.73 & 80.75 \\
\hline
\end{tabular}

IgE, immunoglobulin E. 
and non-serious, the incidence of AEs tended to increase when $40 \mathrm{mg}$ or more of E3024 was administered, and their manifestation including rash also suggested tolerability-related problems. Consequently, it was concluded that for single dose administration of E3024, the maximum permissible dose that would not induce tolerability problems was $20 \mathrm{mg}$.

\subsection{Effects of E3024 on Blood Histamine Levels of Normal Fischer Rats}

We speculated that histamine was involved in rash development in men treated with E3024. Therefore, we treated Fischer rats with E3024 to examine if this increased blood histamine levels. Blood histamine levels were about $0.5 \mu \mathrm{mol} / \mathrm{L}$ in pre-treatment of E3024 in this rat strain. Thirty min after oral administration of E3024, significant increases in blood histamine levels were observed in the $500(p<0.001)$ and $750 \mathrm{mg} / \mathrm{kg}$ groups $(p<$ 0.001) (Figure 5(a)). Next, we examined if the wellknown DPP-IV inhibitors, vildagliptin and valine-pyrrolidide, caused increases in blood histamine levels. Oral administration of vildagliptin at $500 \mathrm{mg} / \mathrm{kg}$ induced no elevation of blood histamine levels $0.5 \mathrm{~h}$ after treatment (Figure 5(b)). Similarly, neither did valine-pyrrolidide increase blood histamine levels (data not shown). Plasma concentrations of E3024, vildagliptin and valine-pyrrolidide were 52, 54 and $221 \mu \mathrm{mol} / \mathrm{L}$, respectively. Regarding E3024, in rat blood the concentration was about 18-fold higher than the $\mathrm{C}_{\max }$ for the 80-mg group of the E3024 clinical trial which was $819 \mathrm{ng} / \mathrm{mL}$ corresponding

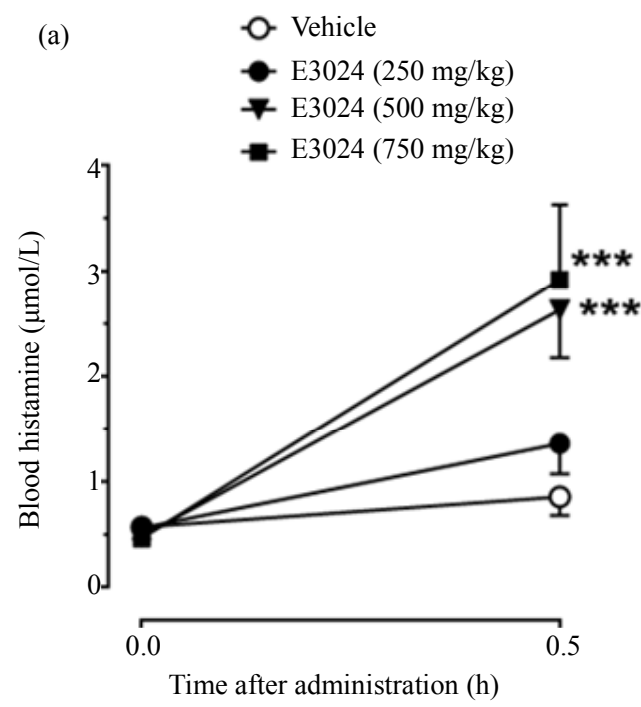

to $2.89 \mu \mathrm{mol} / \mathrm{L}$.

\subsection{Effects of E3024 on Blood Histamine Levels of Mast Cell-Deficient (Ws/Ws) Rats and Wild-Type Homozygous (+/+) Rats}

We investigated whether E3024 increased blood histamine levels in genetically mast cell-deficient rats, comparing their wild-type homozygous rats. In $+/+$ rats, E3024 treatment increased blood histamine concentrations in a dose-dependent manner (Figure 6(a)). A significant increase in blood histamine was found at $1 \mathrm{~h}$ in $500 \mathrm{mg} / \mathrm{kg}$ treatment $(p<0.001)$. On the other hand, no effects were detected in $W s / W s$ rats treated with 500 $\mathrm{mg} / \mathrm{kg}$ E3024 (Figures 6(a) and (b)), although treatment with the same dose caused increases in blood histamine to $>12 \mu \mathrm{mol} / \mathrm{L}$ in $+/+$ rats.

\subsection{In Vitro Histamine Release from Rat Peritoneal Mast Cells and Basophils, and Structure-Activity Relationship (SAR) Study}

To examine which cells, mast cells or basophiles, were involved in E3024-induced histamine release, we collected these cells from normal Fischer rats and subjected them to in vitro assays. At first, we studied the effects of vildagliptin and our DPP-IV inhibitors (E3024, ER319441-15, ER-319433-15 and ER-463809-15) on histamine release from rat mast cells. Concerning the chemical structures, the piperazin-1-yl group of E3024 and ER-319433-15 was replaced with a 3-amino-

(b)
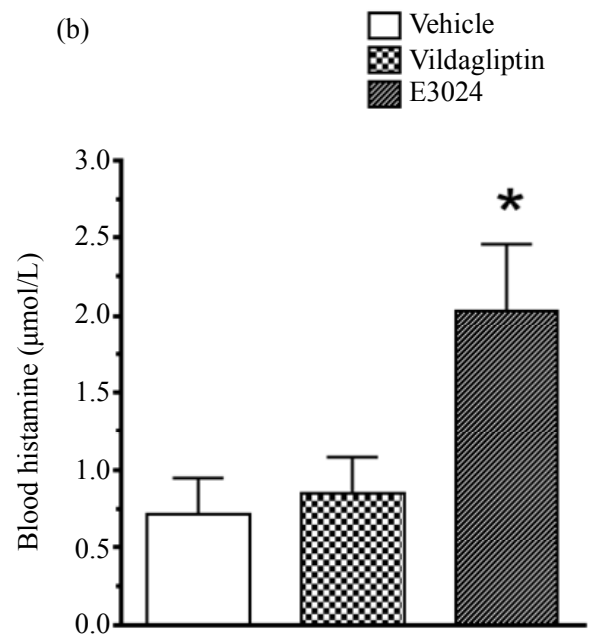

Figure 5. (a) Changes in blood histamine levels in Fischer rats treated with vehicle $(0.5 \%$ methylcellulose, $10 \mathrm{~mL} / \mathrm{kg})$ or E3024 $(250,500$ or $750 \mathrm{mg} / \mathrm{kg})(\mathrm{n}=\mathbf{8})$. Blood histamine was determined before and $0.5 \mathrm{~h}$ after administration. The data were analyzed by two-way repeated measures analysis of variance followed by Bonferroni's test as a post hoc test. ${ }^{* * *}, p<0.001 ;(\mathrm{b})$ Blood histamine levels $0.5 \mathrm{~h}$ after vehicle, vildagliptin $(500 \mathrm{mg} / \mathrm{kg})$ or E3024 $(500 \mathrm{mg} / \mathrm{kg})$ in Fischer rats $(\mathrm{n}=8){ }^{*}, p<0.05$. Values are expressed as the mean \pm standard error of the mean. 

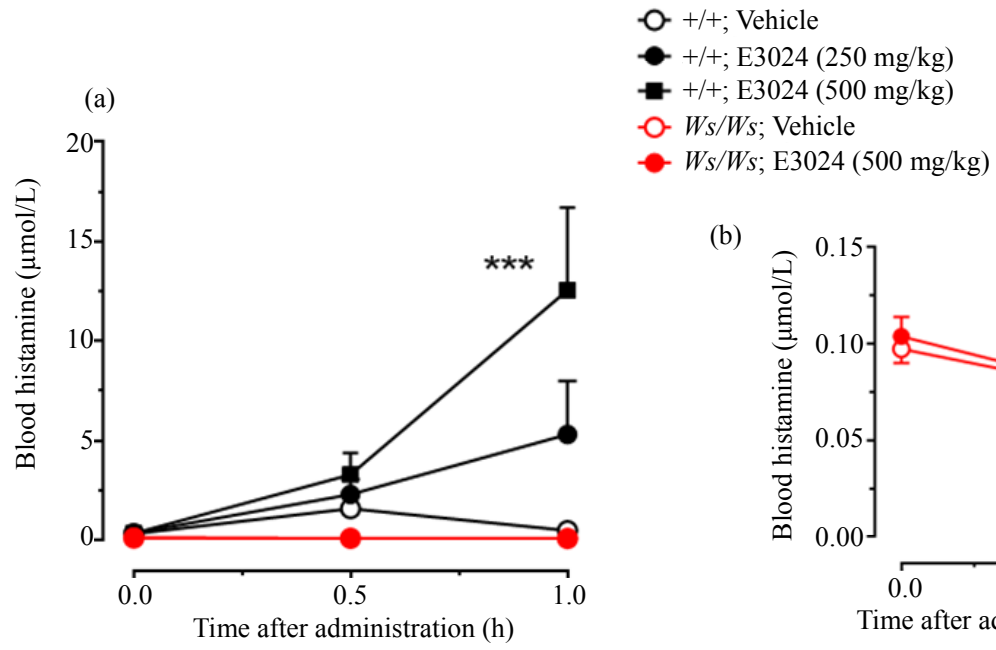

(b)

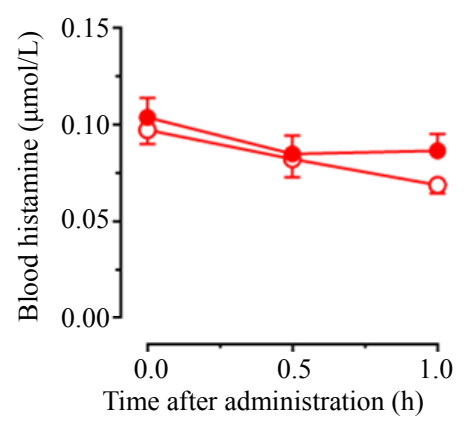

Figure 6. (a) Changes in blood histamine levels in genetically mast cell-deficient $(\mathrm{Ws} / \mathrm{Ws})$ and wild-type normal (+/+) rats. We treated $+/+$ rats with vehicle $(0.5 \%$ methylcellulose, $10 \mathrm{~mL} / \mathrm{kg})$ or $E 3024(250 \mathrm{or} 500 \mathrm{mg} / \mathrm{kg})$, and Ws/Ws rats with vehicle or E3024 $(500 \mathrm{mg} / \mathrm{kg})(\mathrm{n}=7)$. The data were analyzed by two-way repeated measures analysis of variance followed by Bonferroni's test as a post hoc test. $^{* * *}, p<0.001$; (b) Changes in blood histamine levels in Ws/Ws rats are extracted from (a). Values are expressed as the mean \pm standard error of the mean.

piperidin-1-yl group to give ER-319441-15 and ER463809-15, respectively (Figure 1). E3024 and ER319433-15 treatment triggered a significant histamine release in a concentration-dependent fashion (Figure 7(a)). On the other hand, neither ER-319441-15 nor ER-463809-15 caused histamine release like vildagliptin. In the case of whole blood, no histamine release was found until $300 \mu \mathrm{mol} / \mathrm{L}$ of E3024, but it was detected in the treatment of A23187 at $1 \mu \mathrm{mol} / \mathrm{L}$ (Figure 7(b)). To confirm if this in vitro observation was reproduced in in vivo, we administered ER-319441-15 orally to Fischer rats. Although blood histamine was significantly increased $0.5 \mathrm{~h}$ after E3024 treatment at $500 \mathrm{mg} / \mathrm{kg}(p<$ 0.01 ) again, ER-319441-15 caused no increases in blood histamine at $500 \mathrm{mg} / \mathrm{kg}$ (Figure 7(c)).

\section{Discussion}

Pharmacokinetic profiles following administration of single oral doses of E3024 were assessed in healthy adult male volunteers. E3024 was absorbed immediately after administration and eliminated at a mean $t_{1 / 2}$ of 5.34 to $11.68 \mathrm{~h}$. The $\mathrm{CL} / \mathrm{F}$ was almost constant regardless of dose level, while $\mathrm{V}_{\mathrm{z}} / \mathrm{F}$ levels showed an upward tendency in high-dose (40 $\mathrm{mg}$ and $80 \mathrm{mg}$ ) groups. Inappropriate evaluation of the terminal elimination phase in low-dose groups was considered to have influenced the above results. Urinary profiles of E3024 revealed that E3024 was excreted in the urine at a mean cumulative excretion rate of $52.3 \%$ to $63.2 \%$. Therefore, it was estimated that at least $52.3 \%$ to $63.2 \%$ of the orally administered dose would be absorbed. In addition, the $\mathrm{CL}_{\mathrm{R}}$ was greater than the glomerular filtration rate of approximately 125 $\mathrm{mL} / \mathrm{min}$ in healthy adults $(70 \mathrm{~kg}$ ) [19], demonstrating active secretion of E3024 from glomeruli into the urine.

To assess the pharmacodynamic profile of E3024 on single oral administration to healthy male adult volunteers, DPP-IV activity was measured up to $24 \mathrm{~h}$ after dosing, and active GLP-1, insulin, C-peptide, glucagon and glucose levels were measured up to $3 \mathrm{~h}$ after lunch and dinner, which started at 4.5 and $10.5 \mathrm{~h}$ after dosing, respectively. E3024 inhibited plasma DPP-IV activity dose-dependently. A good correlation was found between plasma E3024 concentration and inhibition of DPP-IV activity, and the $\mathrm{IC}_{50}$ value was calculated at $33.7 \mathrm{ng} / \mathrm{mL}$ from the $\mathrm{I}_{\max }$ model. It was reported that when E3024 was added to human plasma, the $\mathrm{IC}_{50}$ value was 0.14 $\mu \mathrm{mol} / \mathrm{L}$ [12], which was equivalent to $39.61 \mathrm{ng} / \mathrm{mL}$. The $\mathrm{IC}_{50}$ value from this clinical study was similar to that previously obtained from the in vitro study. Thus, the pharmacological effect could be explained by the plasma drug concentration.

GLP-1 is an incretin that is released from L-cells in the intestine postprandially as active GLP-1, and then is rapidly degraded to inactive GLP-1 in the body by DPP-IV, a type of serine proteases. Therefore, it was expected that endogenous active GLP-1 would be increased by inhibition of DPP-IV [1-5]. In the placebo group in this study, the level of active GLP-1 increased immediately after food intake, reached a maximum concentration $20 \mathrm{~min}$ after eating, and then decreased. In the E3024 groups administered with doses of $20 \mathrm{mg}$ or more, although there were large variations in measured values, the increase in active GLP-1 after eating was larger than that in 

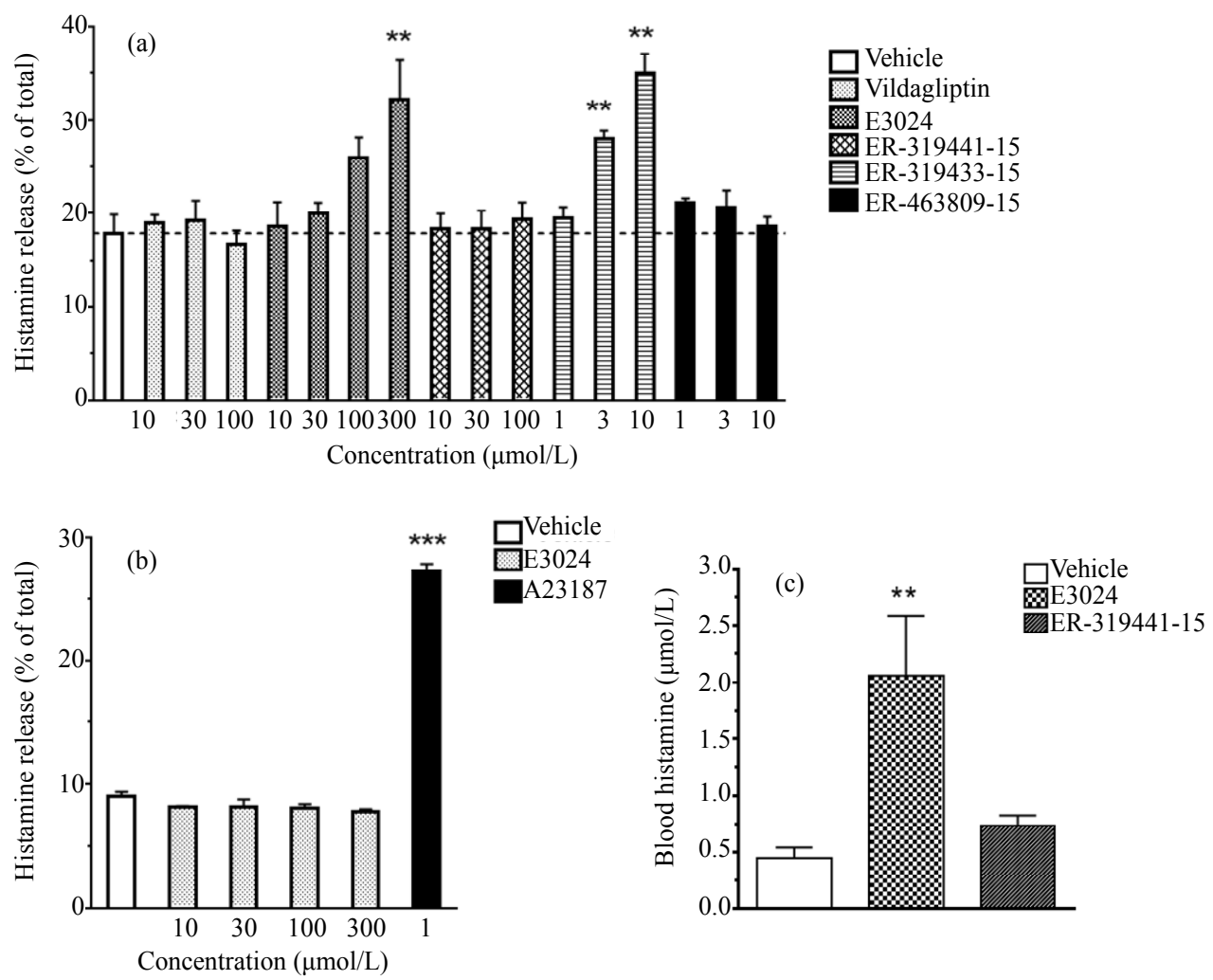

Figure 7. In vitro histamine release from peritoneal mast cells (a) and whole blood (b) of Fischer rats by several dipeptidyl peptidase-IV inhibitors. (a) Peritoneal exudate cells were treated with vehicle (dimethyl sulfoxide; DMSO), vildagliptin (10, 30 or $100 \mu \mathrm{mol} / \mathrm{L})$, E3024 (10, 30, 100 or $300 \mu \mathrm{mol} / \mathrm{L})$, ER-319441-15 (10, 30 or $100 \mu \mathrm{mol} / \mathrm{L})$, ER-319433-15 (1, 3 or $10 \mu \mathrm{mol} / \mathrm{L})$ or ER-463809-15 (1, 3 or $10 \mu \mathrm{mol} / \mathrm{L})(\mathrm{n}=3)$. A broken line indicates vehicle's value; (b) Whole blood was treated with vehicle

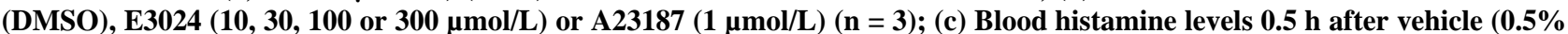
methylcellulose, $10 \mathrm{~mL} / \mathrm{kg})$, E3024 $(500 \mathrm{mg} / \mathrm{kg})$ or ER-319441-15 $(500 \mathrm{mg} / \mathrm{kg})$ in Fischer rats $(\mathrm{n}=8)$. The data were analyzed by one-way analysis of variance followed by Dunnett's test as a post hoc test. ${ }^{* *}, p<0.01 ;{ }^{* * *}, p<0.001$. Values are expressed as the mean \pm standard error of the mean.

the placebo group, suggesting that E3024 could enhance the increase of active GLP-1 after eating. If the study drug was administered just before eating, it is expected that a greater enhancement of active GLP-1 would have been obtained, and there may have also been obvious changes in insulin, C-peptide, glucagon or glucose. Although this study was originally designed to examine the postprandial change in active GLP-1 levels when E3024 was administered just prior to food intake in a later portion of the study, we could not conduct this portion because the study was discontinued before reaching this point.

In this study, E3024 was administered to healthy adults, but the drug had been administered to patients with type 2 diabetes, and a greater enhancing effect may have been obtained. Active GLP-1 can enhance glucose-dependent insulin secretion from islet $\beta$ cells as well as have an inhibitory action on glucagon secretion [1-5]. However, E3024 showed no dose-dependent effects on the postprandial (after-lunch or -dinner) insulin, C-pep- tide, glucagon, or glucose change. Because healthy adults, the target subjects in this study, had normal insulin secretion and did not show postprandial hyperglycemia, it might be difficult to detect the changes in these parameters in these subjects. On the other hand, if the study drug is administered to patients with type 2 diabetes, the changes in these endpoints might be more evident.

Subjective symptoms and objective findings after single oral doses of 5, 10, 20, 40, and $80 \mathrm{mg}$ of E3024 in 48 subjects were as follows: one event (redness) in one subject in the $10 \mathrm{mg}$ group; five events (rash, pruritus) in four subjects in the $40 \mathrm{mg}$ group; 18 events (rash, feeling hot, conjunctival hyperemia, headache, diarrhea, pruritus) in five subjects in the $80 \mathrm{mg}$ group. Although all these events were mild, a greater variety of symptoms and a larger number of the events were observed in the $80 \mathrm{mg}$ group compared with the $40 \mathrm{mg}$ group. These events suggested that drug administration at greater than $80 \mathrm{mg}$ might be capable of eliciting more numerous and more severe events. Thus, administration of 160 and $320 \mathrm{mg}$ of 
E3024 was not conducted.

In eight subjects reporting rash, no changes in eosinophil fraction or non-specific IgE, the parameters for type 1 (immediate) allergy, were observed. DLST was performed on four subjects to examine for the possibility of drug hypersensitivity due to delayed allergy, also with negative results. In three subjects from the $80 \mathrm{mg}$ group, an increasing tendency in histamine level was observed immediately after the onset of rash following study-drug administration. In view of the extremely early onset of rash, the dose-dependency in the rash development profile, and the increase in blood histamine levels, histamine release due to the direct action of E3024 on mast cells was considered most likely to have caused the rash. Because there has been no report of such a frequent development of rash associated with other DPP-IV inhibitors, it is considered unlikely that the rash following E3024 administration had been induced by DPP-IV inhibition. It has been suggested that assessment of the selectivity of DPP-IV inhibition over dipeptidyl peptidase-8 (DPP-8) and dipeptidyl peptidase-9 (DPP-9) is important for obtaining an optimal safety profile of DPP-IV inhibitors in the treatment of type 2 diabetes [20]. The Food and Drug Administration (FDA) requested conduct of skin lesion assessments in monkeys for all DPP-IV inhibitors, based on findings of necrotizing skin lesions due to some DPP-IV inhibitors. The FDA considers the skin lesion a result of off-target inhibition of DPP-8 or DPP-9. Because E3024 was shown to be a highly selective DPP-IV inhibitor which did not inhibit DPP-8 or DPP-9 activity [12], we speculate that inhibition of DPP-8 or DPP-9 is not the cause of the rashes observed with E3024.

We inferred that rash in the clinical trial was related to histamine release which was caused by E3024 directly. Then, we examined if E3024 increased histamine levels in rats. The reasons why we chose rats were: 1) we had pharmacokinetic and pharmacodynamics data of E3024 in rats, and 2) there is a mutant rat strain in which mast cells are deficient. We found that E3024 increased blood histamine levels in normal rats. On the other hand, valinepyrrolidide and vildagliptin had no effects on blood histamine levels, even in the presence of sufficient plasma concentrations. However, there is a large difference in the concentrations of E3024 causing rash in men and increasing blood histamine in the rat. This may be due to different sensitivity between the species: men may be more sensitive to E3024 than rats.

$W s / W s$ rats are deficient in both mucosal-type and connective tissue-type mast cells [21]. The defected gene of $W s$ is c-kit, receptor-type tyrosine kinase [22]. c-kit is a receptor of stem cell factor essential for migration, differentiation, and proliferation of cells, such as hematopoietic stem cells, neural crest-derived melanocytes.
Thus, $W S / W s$ mutant rats manifest depigmentation, anemia, and mast cell deficiency [21]. Histamine is produced in mast cells, basophils, and entero-chromaffinlike (ECL) cells. Basophils of $W s / W s$ rats are not different from wild-type rats in number, and produce histamine [23]. In addition, histamine is synthesized and stored in ECL cells of $W s / W s$ rats [24]. In our study, E3024 increased blood histamine in wild-type homozygous $(+/+)$ rats, while no response was observed in $W s / W s$ rats. In view of the difference in histamine-producing cells between $W s / W s$ and wild-type rats, we concluded that E3024 acted specifically on mast cells to release histamine. The cell-specific effect was also confirmed by the observation that histamine was released from normal rat mast cells, but not from basophils in vitro.

From the in vitro study, we obtained the following SAR: comparing between E3024 and ER-319441-15, the presence of a piperazin-1-yl group on position 2 of the imidazo[4,5- $d]$ pyridazine may be a causal structure for induction of histamine release in rats. Similarly, comparison of ER-319433-15 and ER-463809-15 revealed that the piperazin-1-yl group on position 8 of purine is important in determining whether histamine release occurs. These results showed that a key structure causing histamine release is piperazine linked to a 5,6-membered fused heterocyclic core, namely, either a pyrimidine ring fused to an imidazole ring, or a pyridazine ring fused to an imidazole ring. More interestingly, this piperazineassociated histamine release can be avoided by substitution with 3-amino-piperidine, while maintaining DPP-IV inhibitory activity (data not shown).

Unfortunately, we cannot demonstrate whether or not the 3-amino-piperidin-1-yl compounds do not induce rash clinically. However, among marketed DPP-IV inhibitors, linagliptin (8-[(3R)-3-amino-piperidin-1-yl]-7(but-2-yn-1-yl)-3-methyl-1-[(4-methylquinazolin-2-yl) methyl]-3,7-dihydro- $1 \mathrm{H}$-purine-2,6-dione) [10] has a structure very similar to our compounds and contains a 3-amino-piperidin-1-yl group, not a piperazin-1-yl group, on position 8 of the purine (Figure 8). High incidence of rash as observed in the Phase I trial of E3024 has not been reported in clinical trials of linagliptin: the firstin-man study was performed as a randomized, doubledblind, placebo-controlled Phase I trial in which 63 healthy, male, Caucasian volunteers received the treatment (47 received linagliptin; 16 received placebo) [25]. Once-daily oral doses of linagliptin were $2.5,5,25,50$, $100,200,400$ and $600 \mathrm{mg}$. No rash was observed in this trial. There was a report of a randomized, double-blind, placebo-controlled Phase I trial enrolling eight healthy Japanese male subjects (six received linagliptin and two received placebo per group). Linagliptin was administered as single escalating doses of $1,2.5,5 \mathrm{and} 10 \mathrm{mg}$, or 
<smiles>CC#CCn1c(N2CCC[C@H](N)C2)nc2c1c(=O)n(Cc1nc(C)c3ccccc3n1)c(=O)n2C</smiles>

Linagliptin

Figure 8. Chemical structure of linagliptin.

multiple escalating doses of $2.5,5$ and $10 \mathrm{mg}$ once daily for 12 days [26]. One subject in the $5 \mathrm{mg}$ group showed an increase in histamine concentration. No clinical signs or symptoms attributed to this event were observed, and then they considered unrelated to linagliptin. In addition, no rash was reported in 2523 patients receiving linagliptin $5 \mathrm{mg}$ once daily in eight randomed, double-blind, placebo-controlled Phase III trials lasting 12 to 24 weeks [27]. These facts may support that our speculation that rash could be avoided by the combination of 5- and 6-membered fused heterocyclic rings and 3-aminopiperidine.

In conclusion, we found that E3024 was a compound with favorable pharmacokinetic profiles that inhibited plasma DPP-IV activity dose-dependently with a good correlation between its plasma concentrations and inhibition of DPP-IV activity. Because AEs including rash occurred frequently when $40 \mathrm{mg}$ or more of E3024 was administered, the maximum permissible single dose of E3024 that would not induce tolerability problems was considered to be $20 \mathrm{mg}$. Since superior safety is required for antidiabetic therapy, we decided not to continue further development of E3024. The results of in vivo and in vitro pre-clinical examinations using rats indicated that histamine release from mast cells by E3024 was involved in rash development in men.

\section{Acknowledgements}

The authors wish to express our thanks to the volunteers who participated in this first-in-man study, and staff at Sekino Clinical Pharmacology Clinic. The authors also thank the Eisai study team for E3024 clinical study: Takashi Sato and Hideo Takahira for the measurement of plasma and urine concentrations of E3024; Hiroshi Kuroiwa for clinical data management; Hideaki Miyagishi for statistical analysis; and Hiroshi Arakawa and Shohei Nishimoto for study monitoring. The authors highly appreciated Professor Tetsuo Shiohara, Department of Dermatology, Kyorin University School of Medicine, Tokyo, Japan, for his medical advice on interpretation of rash developing in this study. In addition, we are grateful to Tadashi Nagakura, Katsuhiro Moriya, Yoshihisa Sano, Osamu Takenaka, and Junichi Naga- kawa of Eisai Co., Ltd. for their invaluable advice and support of pre-clinical studies.

\section{REFERENCES}

[1] J. J. Holst and C. F. Deacon, "Inhibition of the Activity of Dipeptidyl-Peptidase IV as a Treatment for Type 2 Diabetes," Diabetes, Vol. 47, No. 11, 1998, pp. 1663-1670. http://dx.doi.org/10.2337/diabetes.47.11.1663

[2] D. J. Drucker, "Enhancing Incretin Action for the Treatment of Type 2 Diabetes," Diabetes Care, Vol. 26, No. 10, 2003, pp. 2929-2940.

http://dx.doi.org/10.2337/diacare.26.10.2929

[3] C. F. Deacon, "Therapeutic Strategies Based on Glucagon-Like Peptide 1," Diabetes, Vol. 53, No. 9, 2004, pp. 2181-2189. http://dx.doi.org/10.2337/diabetes.53.9.2181

[4] J. J. Holst and C. Ørskov, "The Incretin Approach for Diabetes Treatment. Modulation of Islet Hormone Release by GLP-1 Agonism," Diabetes, Vol. 53, Suppl. 3, 2004, pp. S197-S204.

http://dx.doi.org/10.2337/diabetes.53.suppl 3.S197

[5] B. Ahrén, "Dipeptidyl Peptidase-4 Inhibitors. Clinical Data and Clinical Implications," Diabetes Care, Vol. 30, No. 6, 2007, pp. 1344-1350. http://dx.doi.org/10.2337/dc07-0233

[6] D. Kim, L. Wang, M. Beconi, G. J. Eiermann, M. H. Fisher, H. He, G. J. Hickey, J. E. Kowalchick, B. Leiting, K. Lyons, F. Marsilio, M. E. McCann, R. A. Patel, A. Petrov, G. Scapin, S. B. Patel, R. S. Roy, J. K. Wu, M. J. Wyvratt, B. B. Zhang, L. Zhu, N. A. Thornberry and A. E. Weber, "(2R)-4-Oxo-4-[3-(trifluoromethyl)-5,6-dihydro[1, 2,4]triazolo[4,3-a]pyrazin-7(8H)-yl]-1-(2,4,5-trifluorophenyl) butan-2-amine: A Potent, Orally Active Dipeptidyl Peptidase IV Inhibitor for the Treatment of Type 2 Diabetes," Journal of Medicinal Chemistry, Vol. 48, No. 1, 2005, pp. 141-151. http://dx.doi.org/10.1021/jm0493156

[7] E. B. Villhauer, J. A. Brinkman, G. B. Naderi, B. F. Burkey, B. E. Dunning, K. Prasad, B. L. Mangold, M. E. Russell and T. E. Hughes, "1-[[(3-Hydroxy-1-adamantyl) amino]acetyl]-2-cyano-(S)-pyrrolidine: A Potent, Selective, and Orally Bioavailable Dipeptidyl Peptidase IV Inhibitor with Antihyperglycemic Properties," Journal of Medicinal Chemistry, Vol. 46, No. 13, 2003, pp. 27742789. http://dx.doi.org/10.1021/jm0300911

[8] D. J. Augeri, J. A. Robl, D. A. Betebenner, D. R. Magnin, A. Khanna, J. G. Robertson, A. Wang, L. M. Simpkins, P. Taunk, Q. Huang, S. P. Han, B. Abboa-Offei, M. Cap, L. Xin, L. Tao, E. Tozzo, G. E. Welzel, D. M. Egan, J. Marcinkeviciene, S. Y. Chang, S. A. Biller, M. S. Kirby, R. A. Parker and L. G. Hamann, "Discovery and Preclinical Profile of Saxagliptin (BMS-477118): A Highly Potent, Long-Acting, Orally Active Dipeptidyl Peptidase IV Inhibitor for the Treatment of Type 2 Diabetes," Journal of Medicinal Chemistry, Vol. 48, No. 15, 2005, pp. 50255037. http://dx.doi.org/10.1021/jm050261p

[9] J. Feng, Z. Zhang, M. B. Wallace, J. A. Stafford, S. W. Kaldor, D. B. Kassel, M. Navre, L. Shi, R. J. Skene, T. Asakawa, K. Takeuchi, R. Xu, D. R. Webb and S. L. 
Gwaltney, II, "Discovery of Alogliptin: A Potent, Selective, Bioavailable, and Efficacious Inhibitor of Dipeptidyl Peptidase IV," Journal of Medicinal Chemistry, Vol. 50, No. 10, 2007, pp. 2297-2300.

http://dx.doi.org/10.1021/jm0701041

[10] M. Eckhardt, E. Langkopf, M. Mark, M. Tadayyon, L. Thomas, H. Nar, W. Pfrengle, B. Guth, R. Lotz, P. Sieger, H. Fuchs and F. Himmelsbach, "8-(3- $(R)$-Aminopiperidin-1-yl)-7-but-2-ynyl-3-methyl-1-(4-methyl-quinazolin-2-ylmethyl)-3,7-dihydropurine-2,6-dione (BI 1356), a Highly Potent, Selective, Long-Acting, and Orally Bioavailable DPP-4 Inhibitor for the Treatment of Type 2 Diabetes," Journal of Medicinal Chemistry, Vol. 50, No. 26, 2007, pp. 6450-6453. http://dx.doi.org/10.1021/jm701280z

[11] N. Kato, M. Oka, T. Murase, M. Yoshida, M. Sakairi, S. Yamashita, Y. Yasuda, A. Yoshikawa, Y. Hayashi, M. Makino, M. Takeda, Y. Mirensha and T. Kakigami, "Discovery and Pharmacological Characterization of $\mathrm{N}-[2-(\{2-$ [(2S)-2-cyanopyrrolidin-1-yl]-2-oxoethyl \}amino)-2-methylpropyl-2-methylpyrazolo[1,5-a]pyrimidine-6-car-boxamide Hydrochloride (Anagliptin Hydrochloride Salt) as a Potent and Selective DPP-IV Inhibitor," Bioorganicand Medicinal Chemistry, Vol. 19, No. 23, 2011, pp. 72217227. http://dx.doi.org/10.1016/j.bmc.2011.09.043

[12] N. Yasuda, T. Nagakura, T. Inoue, K. Yamazaki, N. Katsutani, O. Takenaka, R. Clark, F. Matsuura, E. Emori, S. Yoshikawa, K. Kira, H. Ikuta, T. Okada, T. Saeki, O. Asano and I. Tanaka, "E3024, 3-But-2-ynyl-5-methyl2-piperazin-1-yl-3,5-dihydro-4H-imidazo[4,5-d] pyridazin4-one Tosylate, Is a Novel, Selective and Competitive Dipeptidyl Peptidase-IV Inhibitor," European Journal of Pharmacology, Vol. 548, No. 1-3, 2006, pp. 181-187. http://dx.doi.org/10.1016/j.ejphar.2006.08.011

[13] K. Yamazaki, T. Inoue, N. Yasuda, Y. Sato, T. Nagakura, O. Takenaka, R. Clark, T. Saeki and I. Tanaka, "Comparison of Efficacies of a Dipeptidyl Peptidase IV Inhibitor and $\alpha$-Glucosidase Inhibitors in Oral Carbohydrate and Meal Tolerance Tests and the Effects of Their Combination in Mice," Journal of Pharmacological Sciences, Vol. 104, No. 1, 2007, pp. 29-38. http://dx.doi.org/10.1254/jphs.FP0061376

[14] K. Yamazaki, N. Yasuda, T. Inoue, E. Yamamoto, Y. Sugaya, T. Nagakura, M. Shinoda, R. Clark, T. Saeki and I. Tanaka, "Effects of the Combination of a Dipeptidyl Peptidase IV Inhibitor and an Insulin Secretagogue on Glucose and Insulin Levels in Mice and Rats," The Journal of Pharmacological and Experimental Therapeutics, Vol. 320, No. 2, 2007, pp. 738-746. http://dx.doi.org/10.1124/jpet.106.112011

[15] T. Hashimoto, H. Kasai, M. Yamada, M. Yamada, H. Sakaki, J. Handa, T. Takizawa and A. Hirata, "Statistical Assessment of Linear Pharmacokinetics in Clinical Pharmacological Studies," Xenobiotic Metabolism and Disposition, Vol. 16, No. 3, 2001, pp. 244-252.

[16] C. F. Deacon, T. E. Hughes and J. J. Holst, "Dipeptidyl Peptidase IV Inhibition Potentiates the Insulinotropic Effect of Glucagon-Like Peptide 1 in the Anesthetized Pig," Diabetes, Vol. 47, No. 5, 1998, pp. 764-769.

\section{http://dx.doi.org/10.2337/diabetes.47.5.764}

[17] S. N. Pramod, Y. P. Venkatesh and P. A. Mahesh, "Potato Lectin Activates Basophils and Mast Cells of Atopic Subjects by Its Interaction with Core Chitobiose of CellBound Non-Specific Immunoglobulin E," Clinical and Experimental Immunology, Vol. 148, No. 3, 2007, pp. 391-401. http://dx.doi.org/10.1111/j.1365-2249.2007.03368.x

[18] K. Kowal, H. Nolte, P. S. Skov and L. M. DuBuske, "Effect of Allergen-Specific Immunotherapy on Recombinant Human Interleukin 3-Mediated Amplification of Allergen-Induced Basophil Histamine Release," Allergy and Asthma Proceedings, Vol. 26, No. 6, 2005, pp. 456-462.

[19] B. Davies and T. Morris, "Physiological Parameters in Laboratory Animals and Humans," Pharmaceutical Research, Vol. 10, No. 7, 1993, pp. 1093-1095. http://dx.doi.org/10.1023/A:1018943613122

[20] G. R. Lankas, B. Leiting, R. S. Roy, G. J. Eiermann, M. G. Beconi, T. Biftu, C. C. Chan, S. Edmondson, W. P. Feeney, H. He, D. E. Ippolito, D. Kim, K. A. Lyons, H. O. Ok, R. A. Patel, A. N. Petrov, K. A. Pryor, X. Qian, L. Reigle, A. Woods, J. K. Wu, D. Zaller, X. Zhang, L. Zhu, A. E. Weber and N. A. Thornberry, "Dipeptidyl Peptidase IV Inhibition for the Treatment of Type 2 Diabetes: Potential Importance of Selectivity over Dipeptidyl Peptidases 8 and 9," Diabetes, Vol. 54, No. 10, 2005, pp 2988-2994. http://dx.doi.org/10.2337/diabetes.54.10.2988

[21] Y. Niwa, T. Kasugai, K. Ohno, M. Morimoto, M. Yamazaki, K. Dohmae, Y. Nishimune, K. Kondo and Y. Kitamura, "Anemia and Mast Cell Depletion in Mutant Rats that Are Homozygous at 'White Spotting $(W s)$ ' Locus," Blood, Vol. 78, No. 8, 1991, pp. 1936-1941.

[22] T. Tsujimura, S. Hirota, S. Nomura, Y. Niwa, M. Yamazaki, T. Tono, E. Morii, H.-M. Kim, K. Kondo, Y. Nishimune and Y. Kitamura, "Characterization of $W_{s} \mathrm{Mu}$ tant Allele of Rats: A 12-Base Deletion in Tyrosine Kinase Domain of c-kit Gene," Blood, Vol. 78, No. 8, 1991, pp. 1942-1946.

[23] T. Kasugai, M. Okada, M. Morimoto, N. Arizono, K. Maeyama, M. Yamada, H. Tei, K. Dohmae, H. Onoue, G. F. Newlands, T. Watanabe, Y. Nishimune, H. R. P. Miller and Y. Kitamura, "Infection of Nippostrongylus brasiliensis Induces Normal Increase of Basophils in Mast Cell-Deficient $W_{S} / W_{S}$ Rats with a Small Deletion at the Kinase Domain of c-kit," Blood, Vol. 81, No. 10, 1993, pp. 2521-2529.

[24] S. Nakamura, H. Watanabe, T. Yokota, H. Matsui, M. Onji and K. Maeyama, "Effect of Rabeprazole on Histamine Synthesis in Enterochromaffin-Like Cells of Mast Cell-Deficient $\left(W_{s} / W s\right)$ Rats," European Journal of Pharmacology, Vol. 394, No. 1, 2000, pp. 9-16. http://dx.doi.org/10.1016/S0014-2999(00)00080-7

[25] S. Hüttner, E. U. Graefe-Mody, B. Withopf, A. Ring and K. A. Dugi, "Safety, Tolerability, Pharmacokinetics, and Pharmacodynamics of Single Oral Doses of BI 1356, an Inhibitor of Dipeptidyl Peptidase 4, in Healthy Male Volunteers," The Journal of Clinical Pharmacology, Vol. 48, No. 10, 2008, pp. 1171-1178.

http://dx.doi.org/10.1177/0091270008323753 
[26] A. Sarashina, S. Sesoko, M. Nakashima, N. Hayashi, A. Taniguchi, Y. Horie, E. U. Graefe-Mody, H.-J. Woerle and K. A. Dugi, "Linagliptin, a Dipeptidyl Peptidase-4 Inhibitor in Development for the Treatment of Type 2 Diabetes Mellitus: A Phase I, Randomized, Double-Blind, Placebo-Controlled Trial of Single and Multiple Escalating Doses in Healthy Adult Male Japanese Subjects," Clinical Therapeutics, Vol. 32, No. 6, 2010, pp. 11881204. http://dx.doi.org/10.1016/j.clinthera.2010.06.004

\begin{abstract}
Abbreviations
Ae, amount of unchanged drug excreted in urine; $\mathrm{AE}$, adverse event; ALT, alanine aminotransferase; AUC, area under the curve; $\mathrm{AUC}_{0 \text {-inf, }}$ area under the plasma concentration-time curve from 0 to infinity; BMI, body mass index; $\mathrm{CI}$, confidence interval; $\mathrm{CL}$, clearance; $\mathrm{CL} / \mathrm{F}$, apparent clearance; $\mathrm{CL}_{\mathrm{R}}$, renal clearance; $\mathrm{C}_{\max }$, maximum observed concentration; DLST, drug-induced lymphocyte stimulation test; DMSO, dimethyl sulfoxide; D-PBS, Dulbecco's phosphate-buffered saline; DPP-IV, dipeptidyl peptidase-IV; DPP-8, dipeptidyl peptidase-8; DPP-9, dipeptidyl peptidase-9; ECG, electrocardiography; ECL, entero-chromaffin-like; EDTA, ethylenediamine-
\end{abstract}

[27] G. Schernthaner, A. H. Barnett, A. Emser, S. Patel, J. Troost, H.-J. Woerle and M. von Eynatten, "Safety and Tolerability of Linagliptin: A Pooled Analysis of Data from Randomized Controlled Trials in 3572 Patients with Type 2 Diabetes Mellitus," Diabetes, Obesity and Metabolism, Vol. 14, No. 5, 2012, pp. 470-478. http://dx.doi.org/10.1111/j.1463-1326.2012.01565.x

tetraacetic acid; ELISA, enzyme-linked immunosorbent assay; F, bioavailability; FDA, Food and Drug Administration; fe, fraction of drug excreted unchanged in urine; GLP-1, glucagon-like peptide-1; $\mathrm{IC}_{50}$, concentration required for $50 \%$ of the maximum inhibition; IgE, immunoglobulin E; LC/MS/MS, liquid chromatographic-tandem mass spectrometry; MC, methycellulose; OTC, over-thecounter; PD, pharmacodynamics; PEC, peritoneal exudate cell; PK, pharmacokinetics; SAR, structure-activity relationship; $\mathrm{t}_{1 / 2}$, terminal half-life; $\mathrm{t}_{\max }$, time to $\mathrm{C}_{\max } ; \mathrm{V}_{\mathrm{z}}$, volume of distribution during the terminal phase; $\mathrm{V}_{\mathrm{z}} / \mathrm{F}$, apparent volume of distribution during the terminal phase 